\title{
Social vulnerability and political advocacy after Hurricane Katrina
}

\author{
T. Buhler Corbin \\ Department of Political Science, Radford University, USA
}

\begin{abstract}
Hurricane Katrina elucidated governmental failures and existing inequities in the affected areas, thus creating an opportunity for policy advocates for historically marginalized populations who rank high on the social vulnerability index to participate in the political process. Using discourse analysis to code the testimony of 240 witnesses who testified in 41 congressional hearings held after Hurricane Katrina, witnesses who advocated for policies that addressed social inequities are identified and their proposals analyzed. Findings indicate that advocates raised contentious issues of race, poverty, environmental justice, and climate change in recovery proposals. Proposals incorporated ideas of sustainability, resilience, and considerations of social equity, representing a significant departure from previous congressional advocacy after disasters. This research increases our understanding of policy change after disasters, particularly the circumstances under which policy advocates can elevate socioeconomic issues to the political agenda.
\end{abstract}

Keywords: Hurricane Katrina, congressional policy advocacy, social vulnerability, race, poverty, environmental justice, sustainability, resilience.

\section{Introduction}

When Hurricane Katrina struck the Gulf Coast of the United States in 2005, the governmental response elucidated policy failures along multiple dimensions, and underscored pervasive social inequalities in New Orleans and the Gulf Coast region. Hurricane Katrina was the first disaster in the United States to highlight the ways in which race, gender, and class intersect and affect individuals' ability to prepare for, respond to, and recover from disasters. Many people affected by the storm were from historically marginalized groups who lacked political 
power, and the resilience to recover after the disaster. The Gulf Coast region has a long history of social inequality and high poverty rates. Mississippi, Louisiana, and Alabama are the first, second, and eighth poorest states in the nation. Combined, these states had a population of 5.8 million in the affected areas when Hurricane Katrina struck; more than one million residents were living in poverty. Poverty rates in the region are nearly double the national average, at $20 \%$ compared to $11 \%$ nationally. New Orleans experienced the highest concentration of damage and had the largest population affected by Hurricane Katrina. Of the 1.3 million residents in the New Orleans metro area, $28 \%$ were living below the poverty level before Hurricane Katrina (Shapiro and Sherman [1]).

The societal and political failures revealed after Hurricane Katrina created a unique opportunity for policy advocates to offer policy change proposals, and shape the political agenda in the initial recovery phases after the disaster. Using discourse analysis to code the testimony of 240 witnesses who testified in 41 congressional hearings held after Hurricane Katrina, witnesses who advocated for policies that addressed social inequities are identified and their proposals analyzed.

\section{Literature review}

\subsection{Policy change after disasters}

This research expands on policy change theories that assign a crucial role to crises or exogenous shocks to the political system in creating an opportunity for rapid and significant policy change. Disasters and crises provide advocates for policy change with an opportunity to advance their preferred policy proposals (e.g. Baumgartner and Jones [2]; Birkland [3, 4]; Kingdon [5]). In the wake of a large disaster or catastrophe, the powerful symbolism of the event, coupled with the accompanying issue expansion, creates a unique window of opportunity for policy change. This is particularly noteworthy in the disaster policy domain, where congressional activity is predominantly confined to authorizing funding for disaster relief efforts (Birkland [6]; Kurtz [7]).

Despite longstanding calls from disaster researchers and practitioners for governmental policies to emphasize disaster mitigation and risk reduction programs, the United States Congress continues to favor funding recovery efforts after disasters strike, rather than allocating resources to fund mitigation and prevention programs. This is unsurprising given the nature of legislative politics, where reelection concerns dominate legislators' decision-making calculus (Mayhew [8]). Disaster mitigation and preparedness policies are low salience 'policies without publics' (May [9]), where technical experts and legislative specialists dominate disaster policymaking between disaster events. Disasters receive little attention from the public or policymakers until they occur.

Although prior research has identified exogenous shocks as crucial for rapid policy change, many unanswered questions remain about how and when we can expect to see changes adopted and implemented. In particular, we know little about the ways in which affected communities participate in the policy process 
after disaster, particularly when those communities are marginalized from the political process. The 'window of opportunity' for policy change is particularly important for politically marginalized groups. "Groups that have traditionally struggled to gain a hearing or see their preferences translated into policy...can use focusing events to gain agenda access" (Birkland [10]). Further, policy studies have not considered the effects of social vulnerability in explaining affected communities' participation in the policy process after disasters. This research addresses this gap.

\subsection{Race, class and social vulnerability in disasters}

Disaster research has documented that disasters exacerbate preexisting social inequities (e.g. Mileti [11]; Peacock et al. [12]; Tatsuki and Hayashi [13]; National Academy of Sciences [14]; Tierney [15]). More recently, disaster scholars have begun to focus attention on the ways in which race, class, and gender intersect, and how this intersection affects communities who experience disasters. This intersection is conceptualized in disaster studies as part of a framework of social vulnerability, understood as, “...partially a product of social inequalities - those social factors and forces that create the susceptibility of various groups to harm, and in turn affect their ability to respond, and bounce back after the disaster. Social vulnerability involves the basic provision of health care, the livability of places, overall indicators of quality of life, and accessibility to lifelines (goods, services, and emergency response personnel), capital, and political representation." (Cutter [16]).

The social vulnerability index provides a framework for understanding the ways in which minorities, women, and people living in poverty, among others, are disproportionately affected at every stage of a disaster. Populations ranking high in social vulnerability measures have historically been marginalized from the political process. Disasters provide opportunities to improve the social, economic, political, and environmental conditions that existed before the disaster occurred. However, often the social vulnerability of populations before a disaster occurs translates into a lack of access to political power after a disaster (Smith and Wenger [17]). Large-scale disasters present opportunities for community members and stakeholders to participate in a meaningful way in the political dialogue and recovery process.

Over the last decade, research about Hurricane Katrina has generated important scholarship that advances our understanding of social inequalities in the Gulf Coast Region, Greater New Orleans, and how these inequalities affect disaster impacts and recovery efforts. The overwhelming majority of this scholarship considers the recovery efforts as they unfolded at the local and state level. In this research, I examine the federal level policymaking process, assessing the role of policy advocacy and congressional action in promoting attention to social inequalities highlighted in the wake of the storm. 


\section{Methods}

This research focuses on the U.S. Congress, which, by institutional design, functions as the primary governmental institution to fund disaster recovery. Although recovery plans are implemented in conjunction with state and local level agencies and organizations, the federal funding decisions and priorities upon which many state, local, and community organizations are dependent are made at the congressional level. Congress is an institution that responds to catastrophic events. Members are accountable to their constituents; they want constituents to perceive them as responsive to governmental problems. The witnesses who testify at congressional hearings and the issues they raise are fundamentally important in the initial stages of the recovery process, as they influence the agenda for future legislative considerations and policy changes.

I used discourse analysis to identify and analyze the recovery policy proposals that witnesses advocated for in the hearings held after Hurricane Katrina. The dataset includes the testimony of 240 witnesses from 41 U.S. House and Senate hearings held about Hurricane Katrina, from September 1, 2005 through February 28, 2006. I obtained the congressional hearings from the Government Printing Office, available online at http://www.gpo.gov. I coded the witness testimony according to the witnesses' type of organization or affiliation. Because this study is primarily interested in identifying whether witnesses engaged in political advocacy on behalf of members of traditionally marginalized populations in the initial policy discussions after Hurricane Katrina, witnesses who represented traditionally marginalized groups, as well as the citizens from the affected communities were of primary interest in this study.

After identifying the witnesses, I coded them based on their affiliation as private citizens or representatives from not-for-profit organizations. The not-forprofit organizations included faith-based organizations and churches, and members of public interest, advocacy, and community groups. After coding the affiliation of each witness, I coded the testimony according to the type of recovery proposals the witnesses advocated, and grouped them into general advocacy areas: environmental justice, issues of race and the legacy of racism in affected communities, class and poverty, affordable housing recovery plans.

\section{Results}

Social justice advocates were present in large numbers in the hearings held after Hurricane Katrina, representing 103 out of 240 witnesses, or nearly $43 \%$ of the total witnesses who testified at the hearings. These witnesses offered proposals that addressed contentious issues of environmental justice, race and the legacy of racism in affected communities, class and poverty, and affordable and safe housing recovery plans. The social justice advocacy issues proposed by 103 witnesses in their testimony are summarized in Table 1 below.

Witnesses discussed environmental issues 44 times, which is the most frequently occurring category. Included in this category were Superfund sites, pollution, particularly from the petrochemical industry, wetland destruction, with 
Table 1: $\quad$ Policy areas witnesses proposed in congressional hearings.

\begin{tabular}{lc}
\hline & Frequency \\
\hline Environmental justice & 44 \\
Affordable housing & 32 \\
Class and poverty & 25 \\
Race and the legacy of racism & 25 \\
\hline Total & 126 \\
\hline
\end{tabular}

Note: Several advocates offered more than one proposal in multiple areas.

particular emphasis on the oil industry's role in the destruction, the need to preserve and restore marshland, global climate change and rising sea levels, and the need to build housing that takes into account geography and social vulnerability. Several witnesses discussed the environmental recovery aspects in terms of cleanup and the legacy of past industrial contamination, particularly from the oil industry. Affordable housing was the second most frequently occurring witness topic, with 32 references to housing issues.

The witness testimony in the affordable housing category included contentious discussions. Although witnesses advocated for members of the affected communities who are traditionally marginalized, and often worked together to form coalitions, they were not united in their policy prescriptions. Many witnesses focused on specific Housing and Urban Development (HUD) proposals and funding for FY06, connecting these proposals with assistance to Gulf Coast residents. Some advocates raised the additional issue of housing discrimination and the practice of 'redlining', a discriminatory practice where financial institutions and other businesses refuse to offer loans in certain geographic areas, such as majority minority neighborhoods. According to witnesses, although illegal, redlining was still widely practiced informally in the region.

Witnesses from several advocacy organizations and charities advocated for changes in housing policies as part of the recovery process. They advocated for the allocation of resources to mitigating the poverty present before the hurricane in order to create more affordable housing options and services for the poor. Organizations that provide emergency housing linked the homelessness after Hurricane Katrina to the broader social problem of homelessness in America. Sharon Daly, Senior Public Policy Advisor for Catholic Charities testified at length about the problems that affected hundreds of thousands of Gulf Coast residents before the disaster, which were exacerbated by Hurricane Katrina. Daly advocated for "Supportive Housing" after Katrina, which links affordable housing to the social services needed for residents so that they can readily access them logistically and financially (H. Hrg 109-77, September 29, 2005).

Roman Nan, President of the National Alliance To End Homelessness, urged involvement of all stakeholders in the recovery planning, including those who were forced to leave and will have the hardest time coming back, which are the poor and low income residents: "The recovery goal is to create communities that 
are better, stronger, and more vibrant. We must work with local, state, federal, and nonprofit agencies to create model urban, rural, and small town environments." In sum, the recurring theme among the advocates for the poor was that "the poor of the past are the vulnerable of the present," and this needs to be a central consideration moving forward into the recovery phase (H. Hrg 10977, September 29, 2005).

Affordable housing and issues of class and poverty are inextricably linked. In addition to housing needs, advocates testified about the difficulties of daily life for the poor, and emphasized a need to plan for accessible services. Witnesses highlighted issues of inequality in their testimony. They advocated for affordable housing safe from hazards, expanded healthcare coverage, and Medicaid reform. Advocates highlighted the need to address poverty, mental illness, unemployment, abuse, hunger, homelessness, and disabilities in the recovery phase of the process.

Concerns over racism and justice are a crucial part of the recovery planning process because of the legacy of racism and discrimination in the region. Witnesses advocated for minority communities' needs and interests, referencing the devastating effects of racism on the Gulf Coast communities twenty-five times in their testimony throughout the 41 hearings held. The importance of race in recovery planning was also raised by the NAACP, as well as by individuals from the communities, such as Reverend Al Dortch, who testified about the lack of aid that low-income African American neighborhoods received from the Red Cross and other relief agencies (H. Hrg 109-74, February 28, 2006).

In sum, the analysis revealed that witnesses were able to leverage a significant opportunity after Hurricane Katrina. Forth three percent of the witnesses who testified at the congressional hearings advocated for groups who are traditionally marginalized from the policy process. Further, witnesses used the opportunity presented by the catastrophe to advocate for proposals that addressed contentious social, political, and environmental issues that are typically neglected after disasters, yet are critical for a successful recovery. Cumulatively, the policy proposals that advocates argued for at the hearings reflected a holistic approach to community recovery. Instead of focusing solely on rebuilding and replicating the infrastructure and the housing in place before Hurricane Katrina struck, this approach is mindful of including the concerns of all stakeholders, paying particular attention to the groups and individuals who are most likely to be left out of the process. Recovery discussions centered on principles of sustainability and social justice. The witnesses represented traditionally marginalized populations and advocated for proposals that addressed the macro social, political, and environmental issues necessary in order to facilitate resilient and sustainable recovery plans.

\section{Conclusions}

This research analyzed the role of advocates in arguing for recovery proposals after Hurricane Katrina. By engaging in a thorough discourse analysis of the congressional testimony of 240 witnesses, it was possible to uncover the 
Table 2: Congressional hearings.

\begin{tabular}{|c|c|c|c|}
\hline $\begin{array}{l}\text { Hearing } \\
\text { Number }\end{array}$ & Date & Committee & Hearing Title \\
\hline $109-235$ & $9 / 06 / 05$ & $\begin{array}{l}\text { Energy and Natural } \\
\text { Resources }\end{array}$ & Gasoline Prices \\
\hline $109-32$ & $9 / 07 / 05$ & Energy and Commerce & $\begin{array}{l}\text { Hurricane Katrina's Effect on } \\
\text { Gasoline Supply and Prices }\end{array}$ \\
\hline $109-266$ & $9 / 08 / 05$ & $\begin{array}{l}\text { Health, Education, } \\
\text { Labor, and Pensions }\end{array}$ & $\begin{array}{l}\text { Roundtable Discussion: Hurricane } \\
\text { Katrina }\end{array}$ \\
\hline $109-53$ & $9 / 14 / 05$ & Financial Services & $\begin{array}{l}\text { Hurricane Katrina: Financial } \\
\text { Institutions' Response }\end{array}$ \\
\hline 109-399 & $9 / 14 / 05$ & $\begin{array}{l}\text { Homeland Security and } \\
\text { governmental affairs }\end{array}$ & $\begin{array}{l}\text { Recovering from Hurricane } \\
\text { Katrina: The Next Phase }\end{array}$ \\
\hline $109-54$ & $9 / 15 / 05$ & Financial Services & $\begin{array}{l}\text { Emergency Housing Needs in the } \\
\text { Aftermath of Katrina }\end{array}$ \\
\hline $109-85$ & $9 / 15 / 05$ & Government Reform & $\begin{array}{l}\text { Back to the Drawing Board: A } \\
\text { First Look at Lessons Learned } \\
\text { from Katrina }\end{array}$ \\
\hline $\mathrm{N} / \mathrm{A}^{*}$ & $9 / 20 / 05$ & $\begin{array}{l}\text { (Senate) Commerce, } \\
\text { Science, and } \\
\text { Transportation }\end{array}$ & $\begin{array}{l}\text { Hurricane Prediction and } \\
\text { Preparation }\end{array}$ \\
\hline $109-74$ & $9 / 22 / 05$ & Energy and Commerce & $\begin{array}{l}\text { The Commerce and Consumer } \\
\text { Protection Implications of } \\
\text { Hurricane Katrina }\end{array}$ \\
\hline $\mathrm{N} / \mathrm{A}^{*}$ & $9 / 22 / 05$ & $\begin{array}{l}\text { (Senate) Science and } \\
\text { Transportation }\end{array}$ & Disaster Communications \\
\hline $109-408$ & $9 / 22 / 05$ & $\begin{array}{l}\text { Small Business and } \\
\text { Entrepreneurship }\end{array}$ & $\begin{array}{l}\text { The Impact of Hurricane Katrina } \\
\text { on Small Businesses }\end{array}$ \\
\hline $109-50$ & $9 / 22 / 05$ & Energy and Commerce & $\begin{array}{l}\text { Assessing Public Health and the } \\
\text { Delivery of Care in the Wake of } \\
\text { Katrina }\end{array}$ \\
\hline $109-789$ & $9 / 28 / 05$ & Finance & $\begin{array}{l}\text { Hurricane Katrina: Community } \\
\text { Rebuilding Needs and } \\
\text { Effectiveness of Past Proposals }\end{array}$ \\
\hline
\end{tabular}


Table 2: Continued.

\begin{tabular}{|c|c|c|c|}
\hline $\begin{array}{l}\text { Hearing } \\
\text { Number }\end{array}$ & Date & Committee & Hearing Title \\
\hline $109-52$ & $9 / 29 / 05$ & Energy and Commerce & $\begin{array}{l}\text { Public Safety Communications } \\
\text { from 9/11 to Katrina: Critical } \\
\text { Public Policy Lessons }\end{array}$ \\
\hline $109-77$ & $9 / 29 / 05$ & Energy and Commerce & $\begin{array}{l}\text { Hurricane Katrina: Assessing the } \\
\text { Present Environmental Status }\end{array}$ \\
\hline $109-279$ & $\begin{array}{l}10 / 6 / 05 \\
10 / 27 / 05\end{array}$ & $\begin{array}{l}\text { Energy and Natural } \\
\text { Resources }\end{array}$ & Hurricanes Katrina and Rita \\
\hline $109-801$ & $10 / 06 / 05$ & Finance & The Future of the Gulf Coast \\
\hline $109-34$ & $10 / 07 / 05$ & Small Business & $\begin{array}{l}\text { Small Business and Hurricane } \\
\text { Katrina: Rebuilding the Economy }\end{array}$ \\
\hline$* \mathrm{~N} / \mathrm{A}$ & $10 / 17 / 05$ & $\begin{array}{l}\text { Senate Democratic } \\
\text { Policy Committee }\end{array}$ & $\begin{array}{l}\text { Handling of Federal Contracts } \\
\text { After Hurricane Katrina }\end{array}$ \\
\hline $109-830$ & $\begin{array}{l}10 / 18 / 05 \\
1 / 25 / 05 \\
2 / 2 / 06\end{array}$ & $\begin{array}{l}\text { Banking, Housing, and } \\
\text { Urban Affairs }\end{array}$ & $\begin{array}{l}\text { The Future of the National Flood } \\
\text { Insurance Program }\end{array}$ \\
\hline $109-35$ & $10 / 18 / 05$ & $\begin{array}{l}\text { Transportation and } \\
\text { Infrastructure }\end{array}$ & $\begin{array}{l}\text { A Vision and Strategy For } \\
\text { Rebuilding New Orleans }\end{array}$ \\
\hline $109-36$ & $10 / 20 / 05$ & $\begin{array}{l}\text { Transportation and } \\
\text { Infrastructure }\end{array}$ & $\begin{array}{l}\text { Expert Views on Hurricane and } \\
\text { Flood Protection and Water } \\
\text { Resources Planning for a Rebuilt } \\
\text { Gulf Coast }\end{array}$ \\
\hline $109-18$ & $10 / 26 / 05$ & Agriculture & $\begin{array}{l}\text { Current Impact of Mississippi } \\
\text { River Transportation on } \\
\text { Agricultural Markets }\end{array}$ \\
\hline $109-38$ & $10 / 27 / 05$ & $\begin{array}{l}\text { Transportation and } \\
\text { Infrastructure }\end{array}$ & $\begin{array}{l}\text { Recuing Hurricane and Flood } \\
\text { Risk in the Nation }\end{array}$ \\
\hline $109-110$ & $11 / 1 / 05$ & Government Reform & Historic Preservation vs. Katrina \\
\hline $109-1000$ & $11 / 2 / 05$ & $\begin{array}{l}\text { Environment and Public } \\
\text { Works }\end{array}$ & $\begin{array}{l}\text { The Second in a Series of Two } \\
\text { Hearing to Discuss the Response } \\
\text { to Hurricane Katrina }\end{array}$ \\
\hline $109-1007$ & $11 / 8 / 05$ & $\begin{array}{l}\text { Environment and Public } \\
\text { Works }\end{array}$ & $\begin{array}{l}\text { Impact of Certain Governmental } \\
\text { Contractor Liability Proposals on } \\
\text { Environmental Laws }\end{array}$ \\
\hline
\end{tabular}


Table 2: Continued.

\begin{tabular}{|c|c|c|c|}
\hline $\begin{array}{l}\text { Hearing } \\
\text { Number }\end{array}$ & Date & Committee & Hearing Title \\
\hline 109-1009 & $11 / 9 / 05$ & $\begin{array}{l}\text { Environment and Public } \\
\text { Works }\end{array}$ & $\begin{array}{l}\text { Forming a Comprehensive } \\
\text { Approach to Meeting the Water } \\
\text { needs of Coastal Louisiana in the } \\
\text { wake of Hurricanes Karina and } \\
\text { Rita }\end{array}$ \\
\hline $109-35$ & $11 / 10 / 05$ & Resources & NEPA Litigation \\
\hline $109-32$ & $11 / 10 / 05$ & Science & $\begin{array}{l}\text { Role of Social Science Research } \\
\text { in Disaster Preparedness and } \\
\text { Response }\end{array}$ \\
\hline $109-538$ & $11 / 16 / 05$ & $\begin{array}{l}\text { Homeland Security and } \\
\text { Governmental Affairs }\end{array}$ & $\begin{array}{l}\text { Hurricane Katrina: What can the } \\
\text { Government Learn from the } \\
\text { Private Sector's Response? }\end{array}$ \\
\hline $109-1013$ & $11 / 17 / 05$ & $\begin{array}{l}\text { Environment and Public } \\
\text { Works }\end{array}$ & $\begin{array}{l}\text { Evaluate the Degree to Which the } \\
\text { Preliminary Findings on the } \\
\text { Failure of the Levees are being } \\
\text { Incorporated into the Restoration } \\
\text { of Hurricane Protection }\end{array}$ \\
\hline $109-52$ & $12 / 13 / 05$ & Ways and Means & $\begin{array}{l}\text { To Review the Response by } \\
\text { Charities to Hurricane Katrina }\end{array}$ \\
\hline $109-69$ & $12 / 15 / 05$ & Resources & $\begin{array}{l}\text { An Assessment of Hurricanes } \\
\text { Katrina and Rita on Gulf of } \\
\text { Mexico Fishery }\end{array}$ \\
\hline $109-69$ & $1 / 13 / 06$ & Financial Services & $\begin{array}{l}\text { Housing Options in the Aftermath } \\
\text { of Hurricanes Katrina and Rita }\end{array}$ \\
\hline $109-70$ & $1 / 14 / 06$ & Financial Services & $\begin{array}{l}\text { Housing Options in the Aftermath } \\
\text { of Hurricanes Katrina and Rita }\end{array}$ \\
\hline 109-1009 & $11 / 9 / 05$ & $\begin{array}{l}\text { Environment and Public } \\
\text { Works }\end{array}$ & $\begin{array}{l}\text { Forming a Comprehensive } \\
\text { Approach to Meeting the Water } \\
\text { needs of Coastal Louisiana in the } \\
\text { wake of Hurricanes Karina and } \\
\text { Rita }\end{array}$ \\
\hline $109-35$ & $11 / 10 / 05$ & Resources & NEPA Litigation \\
\hline
\end{tabular}


Table 2: Continued.

\begin{tabular}{|c|c|c|c|}
\hline $\begin{array}{l}\text { Hearing } \\
\text { Number }\end{array}$ & Date & Committee & Hearing Title \\
\hline $109-32$ & $11 / 10 / 05$ & Science & $\begin{array}{l}\text { Role of Social Science Research } \\
\text { in Disaster Preparedness and } \\
\text { Response }\end{array}$ \\
\hline $109-538$ & $11 / 16 / 05$ & $\begin{array}{l}\text { Homeland Security and } \\
\text { Governmental Affairs }\end{array}$ & $\begin{array}{l}\text { Hurricane Katrina: What can the } \\
\text { Government Learn from the } \\
\text { Private Sector's Response? }\end{array}$ \\
\hline $109-1013$ & $11 / 17 / 05$ & $\begin{array}{l}\text { Environment and Public } \\
\text { Works }\end{array}$ & $\begin{array}{l}\text { Evaluate the degree to which the } \\
\text { Preliminary Findings on the } \\
\text { Failure of the Levees are being } \\
\text { incorporated into the restoration } \\
\text { of Hurricane Protection }\end{array}$ \\
\hline $109-52$ & $12 / 13 / 05$ & Ways and Means & $\begin{array}{l}\text { To Review the Response by } \\
\text { Charities to Hurricane Katrina }\end{array}$ \\
\hline $109-69$ & $12 / 15 / 05$ & Resources & $\begin{array}{l}\text { An Assessment of Hurricanes } \\
\text { Katrina and Rita on Gulf of } \\
\text { Mexico Fishery }\end{array}$ \\
\hline $109-69$ & $1 / 13 / 06$ & Financial Services & $\begin{array}{l}\text { Housing Options in the Aftermath } \\
\text { of Hurricanes Katrina and Rita }\end{array}$ \\
\hline $109-70$ & $1 / 14 / 06$ & Financial Services & $\begin{array}{l}\text { Housing Options in the Aftermath } \\
\text { of Hurricanes Katrina and Rita }\end{array}$ \\
\hline $109-115$ & $1 / 26 / 06$ & Energy and Commerce & $\begin{array}{l}\text { Hospital Disaster Preparedness: } \\
\text { Past, Present, and Future }\end{array}$ \\
\hline $109-807$ & $2 / 6 / 06$ & $\begin{array}{l}\text { Homeland Security and } \\
\text { Governmental Affairs }\end{array}$ & $\begin{array}{l}\text { Managing Law Enforcement and } \\
\text { Communications in a Catastrophe }\end{array}$ \\
\hline $109-74$ & $2 / 28 / 06$ & Financial Services & $\begin{array}{l}\text { Fair Housing Issues In the Gulf } \\
\text { Coast in the Aftermath of } \\
\text { Hurricanes Katrina and Rita }\end{array}$ \\
\hline$* * \mathrm{~N} / \mathrm{A}$ & $12 / 6 / 05$ & $\begin{array}{l}\text { Select Bipartisan } \\
\text { Committee } \\
\text { to Investigate the } \\
\text { Preparation for } \\
\text { and Response to } \\
\text { Hurricane Katrina }\end{array}$ & $\begin{array}{l}\text { Hurricane Katrina: Voices from } \\
\text { Inside the Storm }\end{array}$ \\
\hline
\end{tabular}


arguments and advocacy work of the witnesses who testified on behalf of traditionally marginalized groups affected by the disaster. Although disaster scholars endorse recovery models that include all affected stakeholders, there remains a dearth of research about the conditions and processes by which those models are advanced, particularly at the federal level in the initial stages of the process. This research is an initial contribution to this question, and is a point of departure for understanding the initial phases of recovery after Hurricane Katrina.

After Hurricane Katrina, the longstanding social inequality and poverty in the region was revealed to the nation and the world, and dominated national and international news media outlets. Social justice advocates used the national attention to these pervasive, preexisting inequalities as an opportunity to advocate for policies that addressed these inequalities during the disaster recovery process. Advocates testified in the congressional hearings held after Hurricane Katrina, and proposed policy changes that explicitly recognized the intersection of race, gender, and class, particularly as these considerations influenced proposals about affordable housing, environmental justice, and access to human services. The results of this research contribute to our understanding of the ways in which social justice advocacy translates into policy change. Further, it contributes to our understanding of policy agenda setting and policy change after disasters.

It is significant that policy advocates were successful in gaining agenda access, and that they proposed policy changes that took race and class into account during the policy agenda-setting policy stage, particularly since typically after disasters, congressional hearings focus on criticisms of relief efforts and distributive politics. While it is significant that social justice advocates successfully gained access to the congressional policymaking process and proposed policy changes that took race, environmental justice, housing, and class into account, an important question remains as to whether these advocacy efforts were ultimately successful in promoting legislative changes, and I am currently exploring this question in a subsequent research project.

\section{References}

[1] Shapiro, I. \& Sherman, A. Essential Facts About The Victims of Hurricane Katrina. http://www.cbpp.org/research/essential-facts-about-the-victimsof-hurricane-katrina, 2005.

[2] Baumgartner, F. R. \& Jones, B. D., Agendas and Instabilities in American Politics. Chicago and London: The University of Chicago Press, 1993.

[3] Birkland, T. A., After Disaster: Agenda Setting, Public Policy, and Focusing Events. Washington D.C.: Georgetown University Press, 1997.

[4] Birkland, T. A. Lessons of Disaster: Policy Change After Catastrophic Events. Washington D.C.:Georgetown University Press, 2006.

[5] Kingdon, J. W. Agendas, Alternatives, and Public Policies 2nd edition. New York: Longman, 1995. 
[6] Birkland, T. A., After Disaster: Agenda Setting, Public Policy, and Focusing Events. Washington D.C.: Georgetown University Press, 1997.

[7] Kurtz, R. S. Coastal Oil Pollution: Spills, Crisis, and Policy Change. Review of Policy Research , 21(2), 201-219, 2004.

[8] Mayhew, D. R. Congress: The Electoral Connection, 2nd ed. Yale University Press, 2004.

[9] May, P. Recovering From Catastrophes: Federal Disaster Relief Policy and Politics. Praeger, 1985.

[10] Birkland, T. A., After Disaster: Agenda Setting, Public Policy, and Focusing Events. Washington D.C.: Georgetown University Press, pp. 3334, 1997.

[11] Mileti, D. Disasters by Design: A Reassessment of Natural Hazards in the United States. Washington D.C.: Joseph Henry Press, 1999.

[12] Peacock, W. G., Morrow, B. H. \& Gladwin, H. Hurricane Andrew: Ethnicity, gender, and the sociology of disasters. Miami: Florida International University, 2000.

[13] Tatsuki, S. \& Hayashi, H. "Seven Critical Element model of life recovery: General linear model analyses of the 2001 Kobe panel survey data." 2nd Workshop for Comparative Study on Urban Earthquake Disaster Management. Kyoto: Disaster Prevention Research Institute, 2002.

[14] National Academies of Science. Facing hazards and disastsers: Understanding human dimensions. National Academies Press: Washington D.C., 2006.

[15] Tierney, K. From the margins to the mainstream? Disaster research at the crossroads. Annual Review of Sociology, 503-525, 2007.

[16] Cutter, S. "The Geography of Social Vulnerability: Race, Class, and Catastrophe." June 11. http://understandingkatrina.ssrc.org/Cutter/. (Accessed May 22, 2013), 2006.

[17] Smith, G. B. \& Wenger, D. Sustainable Disaster Recovery: Operationalizing An Existing Agenda. In H. Rodriguez, E. L. Quarantelli \& R. R. Dynes, Handbook of Disaster Research, pp. 234-257, New York: Springer, 2007. 